\title{
Jajanan Sehat Dan Bahaya Junk Food Pada Orang Tua Dan Sekolah Dengan Metode Digital
}

\author{
Reni Asmara Ariga ${ }^{1^{*}}$, Siti Zahara Nasution ${ }^{2}$, Cholina Trisa Siregar $^{3}$, Lufthiani ${ }^{4}$, \\ Fajar Amanah Ariga ${ }^{5}$ \\ 1-5 Universitas Sumatera Utara \\ ${ }^{*}$ Corresponding author \\ E-mail: reni.asmara.ariga@usu.ac.id
}

Article History:

Received: 19-11-2020

Revised: 16-01-2021

Accepted: 19-01-2021

Keywords:

\begin{abstract}
Pertumbuhan dan perkembangan pada anak dalam usia sekolah harus optimal seperti memberikan nutrisi dengan kuantitas dan kualitas dengan baik dan benar, bila tidak benar dapat menyebabkan gangguan yang terjadi pada organ tubuh pada anak usia sekolah. Cara efektif yang dapat dilakukan adalah dengan promosi kesehatan mengenai jajanan sehat dan bahaya junk food. Kegiatan pengabdian kepada masyarakat ini dimaksudkan kepada orang tua dan sekolah dalam mengurangi kontribusi anak usia sekolah terhadap jajanan kaki lima yang tidak aman dan tidak sehat. Kegiatan promosi kesehatan di SD Muhammadiyah I Medan dilakukan pada bulan Maret sampai Agustus menggunakan metode digital yang disampaikan melalui Whatsapp group, dilakukan pre dan posttest kemudian pemaparan dengan menggunakan media leaflet, video dan diikuti dengan diskusi. Terjadi peningkatan pengetahuan dan sikap orangtua dan sekolah dalam makanan sehat dan bahaya junk food.
\end{abstract}

Digital, Jajanan Sehat, Anak Usia Sekolah

\section{Pendahuluan}

Anak pada usia sekolah merupakan generasi penerus bangsa. Mereka adalah investasi bangsa. Kualitas anak-anak saat ini sangat berpengaruh besar terhadap kualitas bangsa di masa yang akan datang. Upaya untuk meningkatkan kualitas sumber daya manusia harus berkesinambungan dan sistematis dan juga harus dilakukan sejak dini. Nutrisi dengan kuantitas dan kualitas yang benar dan baik juga mempengaruhi tumbuh kembang anak pada usia sekolah. Pada masa tumbuh kembang anak usia sekolah, pemberian asupan makanan atau nutrisi tidak semuanya dapat dilakukan dengan sempurna. Sering juga ada kendala dalam memberikan makanan pada anak usia sekolah yang menyimpang dan tidak benar. Penyimpangan yang terjadi dapat mengakibatkan gangguan pada sistem tubuh anak usia sekolah dan di banyak organ anak tersebut. Penyakit bawaan atau disebut juga dengan Foodborne diseases adalah masalah kesehatan yang paling utama dan sering terjadi di masyarakat dan juga di banyak negara. Foodborne biasanya ditafsir sebagai penyakit yang tidak serius sehingga penyakit ini kerap kurang diperhatikan (Widodo, 2008), akan tetapi anak usia sekolah yang terkena Foodborne pada tahun 2010 ditafsirkan lebih dari 500 juta anak dan 30\% dari 1 juta anak di dunia mengalami penyakit Foodborne (Nurmawati et al., 2019). 
Pada umumnya makan di warung sekitar sekolah atau kantin serta kebiasaan memakan junk food sudah menjadi kebiasaan yang menjadi masalah pada kesehatan saat ini. Street vendors atau biasa dikenal dengan jajanan yang dijual oleh pedagang pinggir jalan atau pedagang kaki lima. Menurut FAO, Street vendors merupakan minuman maupun makanan yang disajikan dan dijual oleh pedagang yang ada di tempat-tempat keramaian umum maupun di sekitar kaki lima atau jalanan yang langsung dikonsumsi atau dimakan tanpa persiapan atau pengolahan yang lebih lanjut. Makanan jajanan yang menarik, mudah dijumpai, bervariasi dan tergolong murah adalah makanan yang sering dijumpai pada jajanan kaki lima (Ariga et al., 2020; Nurmawati et al., 2019; WHO, 2000).

Dalam sehari, biasanya seperempat waktu anak di usia sekolah pada umumnya di sekolah. Dalam penelitian dari Jakarta, uang jajan anak di usia sekolah sekarang berkisar Rp. 5.000 - Rp. 7.000 per hari, bahkan ada anak di usia sekolah memiliki uang jajan yang mencapai Rp. 10.000. Ada sekitar $5 \%$ anak usia sekolah yang membawa bekal dari rumahnya masing-masing. Oleh karena itu, kebanyakan anak usia sekolah lebih banyak terpapar makanan jajanan dari kaki lima dikarenakan kebanyakan anak usia sekolah memiliki kemampuan untuk membeli jajanan tersebut. Pada dasarnya, makanan yang ada di jajanan kaki lima sangat berpengaruh untuk asupan energi anak usia sekolah yaitu sebanyak $36 \%$, zat besi sebanyak $52 \%$ dan protein sebanyak $29 \%$. Oleh karena itu, jajanan kaki lima sangat berperan penting untuk prestasi belajar anak dan pertumbuhan anak usia sekolah. Akan tetapi, keamanan dari jajanan kaki lima dari segi kimiawi maupun dari segi mikrobiologis masih perlu dipertanyakan. Penelitian dari Bogor mengungkapkan bahwa adanya Salmonella Paratyphi A di $25 \%$ - 50\% pada sampel minuman dari street vendors (Ariga et al., 2020; Lubis, 2009).

Penelitian dari daerah Jakarta Timur menyatakan jenis dari jajanan kaki lima yang kerap dimakan oleh anak usia sekolah yaitu otak-otak, bakso dengan saus, lontong, tahu goreng, mie, ketan uli, cilok dan es sirup. Hasil uji laboratorium mengungkapkan bahwa pada bakso dan otak-otak ditemukan adanya borax. Pada mie kuning basah dan tahu goreng ditemukan adanya formalin. Pada es sirup berwarna merah ditemukan adanya rhodamin B. Bukan hanya cemaran mikrobiologis saja, ada juga cemaran kimiawi yang didapatkan pada street vendors berupa penggunaan Bahan Tambahan Pangan yang ilegal, yaitu formalin atau yang biasa dikenal dengan pengawet untuk mayat, borax yang biasa dikenal dengan pengempal yang mengandung logam berat boron, methanil yellow yang biasa dikenal dengan pewarna kuning digunakan pada tekstil dan rhodamin B yang biasa dikenal dengan pewarna merah digunakan pada tekstil. Semua bahan tersebut dapat terakumulasi di tubuh manusia dan juga bersifat racun (karsinogenik). Jika seseorang mengkonsumsi bahan-bahan tersebut dalam jangka waktu panjang, maka akan menyebabkan berbagai penyakit, seperti tumor dan kanker di organ tubuh seseorang. Sudah terungkap bahwa efek samping yang terjadi dari makanan yang mengandung bahan tersebut ternyata bisa berpengaruh pada fungsi otak, 
termasuk juga gangguan pada perilaku di anak usia sekolah (Kurniasih et al., 2010; Lubis, 2009).

Gangguan perilaku yang dapat terjadi yaitu gangguan pada saat tidur, gangguan emosi pada anak, gangguan konsentrasi pada saat belajar, memperberat gejala pada penderita autism dan juga terjadinya hiperaktif pada anak. Ada juga pengaruh dalam waktu singkat pada penggunaan BTP, yaitu BTP dapat menyebabkan timbulnya gejala seperti mual, pusing, muntah, kesulitan saat buang air besar maupun diare. Joint Expert Committee on Food Additives (JECFA) dari WHO yang mengevaluasi dan mengatur standar BTP dan melarang untuk menggunakan bahan kimia pada makanan. Standar ini juga sudah diadopsi oleh Badan POM (BPOM) dan Departemen Kesehatan RI (Depkes RI) melalui Peraturan Menkes no. 722/Menkes/Per/IX/1998 (Kurniasih et al., 2010; WHO, 2000).

Pada Pengabdian masyarakat ini objek/sasaran adalah : Guru, Guru dapat berperan sebagai konselor, motivator, manajer, pemberi instruksi, model dalam memberi petunjuk yang baik misalnya dalam jajanan sehat dan junk food. Murid/ siswa sebagai generasi emas yang bila tidak mendapatkan asupan gizi yang baik dapat mempengaruhi perilaku konsumsinya sampai dewasa dan berdampak juga pada pertumbuhan dan perkembangan, Orang Tua, orang tua adalah guru dan model yang terbaik yang paling dekat/ mempunyai ikatan emosional yang baik dalam memberikan contoh dalam konsumsi makanan yang bergizi, masyarakat/ petugas kantin, yang juga berperan aktif dalam mendukung tersedianya makanan/ jajanan yang bergizi. Untuk menciptakan generasi emas sebagai konsumen cerdas pun tidak cukup dengan melakukan sosialisasi saja namun perlu kerjasama aktif para pelaku usaha makanan untuk menciptakanan makanan yang bergizi baik.

Pengabdian kepada masyarakat ini dilakukan dengan metode digital/ media online kinerja dapat terukur kita dapat mengetahui jumlah yang melihat informasi promosi kesehatan tersebut, membagikan kepada teman - teman.

\section{Metode}

Promosi kesehatan tentang jajanan sehat dan bahaya junk food pada orang tua dan sekolah dengan metode digital disampaikan melalui Whatsapp group. Pelatihan ini dilaksanakan pada bulan Maret sampai September 2020 di SD Muhammadiyah I pada Jl. Demak No.3, Sei Rengas Permata Medan. Pelaksanaan pengabdian dimulai dari melakukan koordinasi dengan pihak sekolah kemudian mengidentifikasi nomor Whatsapp guru, orang tua dengan mendapatkan data dari sekolah dan melakukan pengkajian data demografi.

Setelah semua guru dan orang tua bergabung ke dalam Whatsapp group, tim memberikan pretest dengan menilai tingkat pengetahuan dan sikap tentang jajanan sehat dan bahaya junk food dengan memberikan link berisikan kuesioner dengan beberapa pertanyaan untuk menilai pengetahuan dan sikap orangtua dan pihak sekolah terhadap makanan jajanan di sekitar sekolah. Selanjutnya tim melakukan promosi kesehatan selama 3 bulan dengan cara mengirim pesan singkat yang berisi 
tentang konsep jajanan sehat dan bahaya junk food yang dimulai pada bulan Mei dan berakhir pada bulan Agustus 2020. Promosi kesehatan yang disampaikan dilakukan role play dengan cara merekam video terkait jajanan sehat dan junk food. Setelah itu dilakukan posttest. Mengevaluasi kegiatan dan penyerahan sarana dan prasarana. Detail penelitian dapat dilihat pada Gambar 1, Gambar 2, Gambar 3 dan Gambar 4.

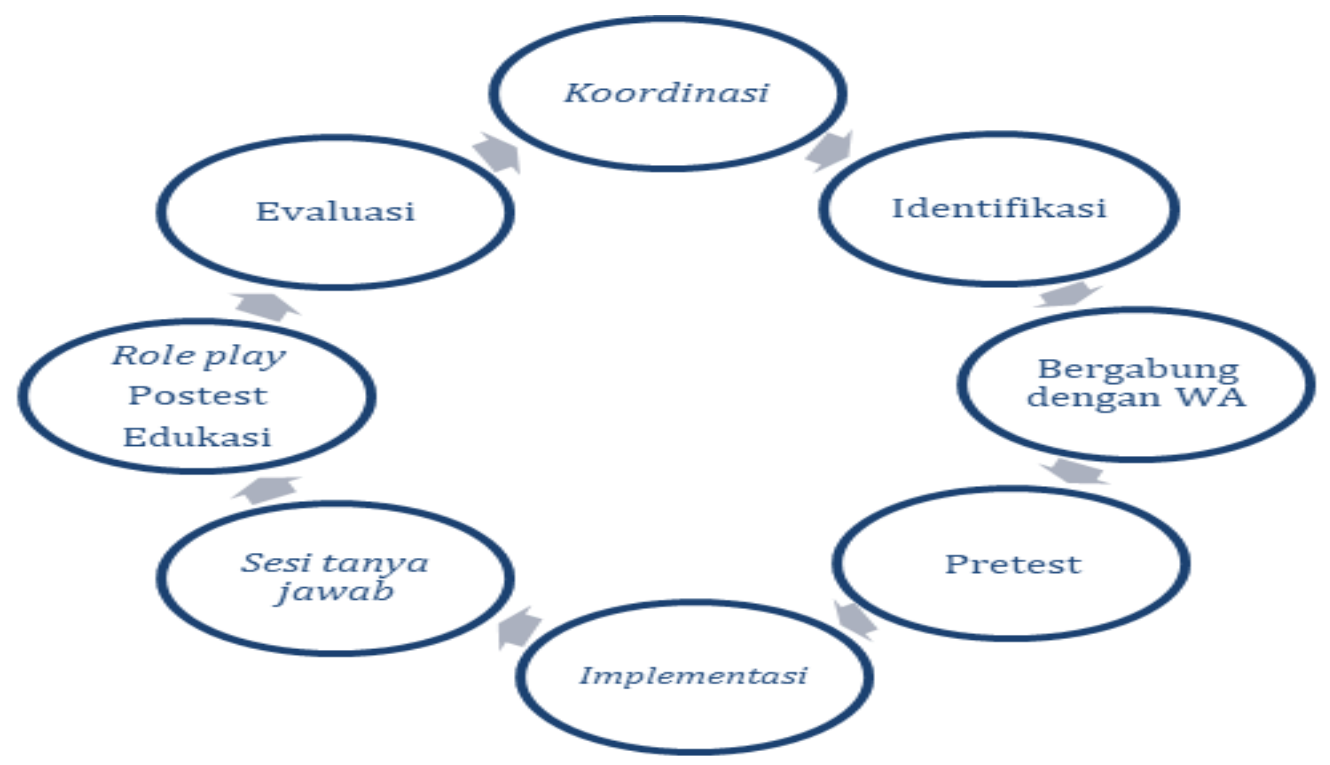

Gambar 1. Pelaksanaan Pengabdian

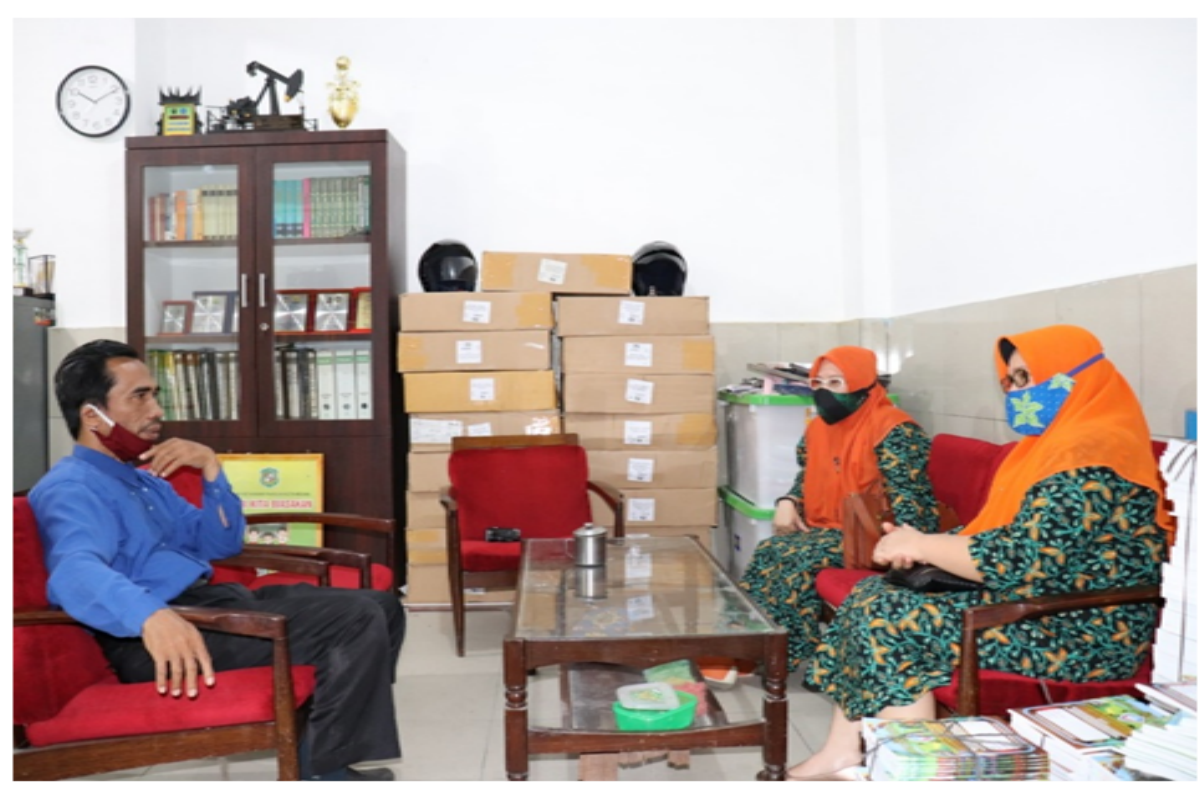

Gambar 2. Koordinasi dengan pihak sekolah 


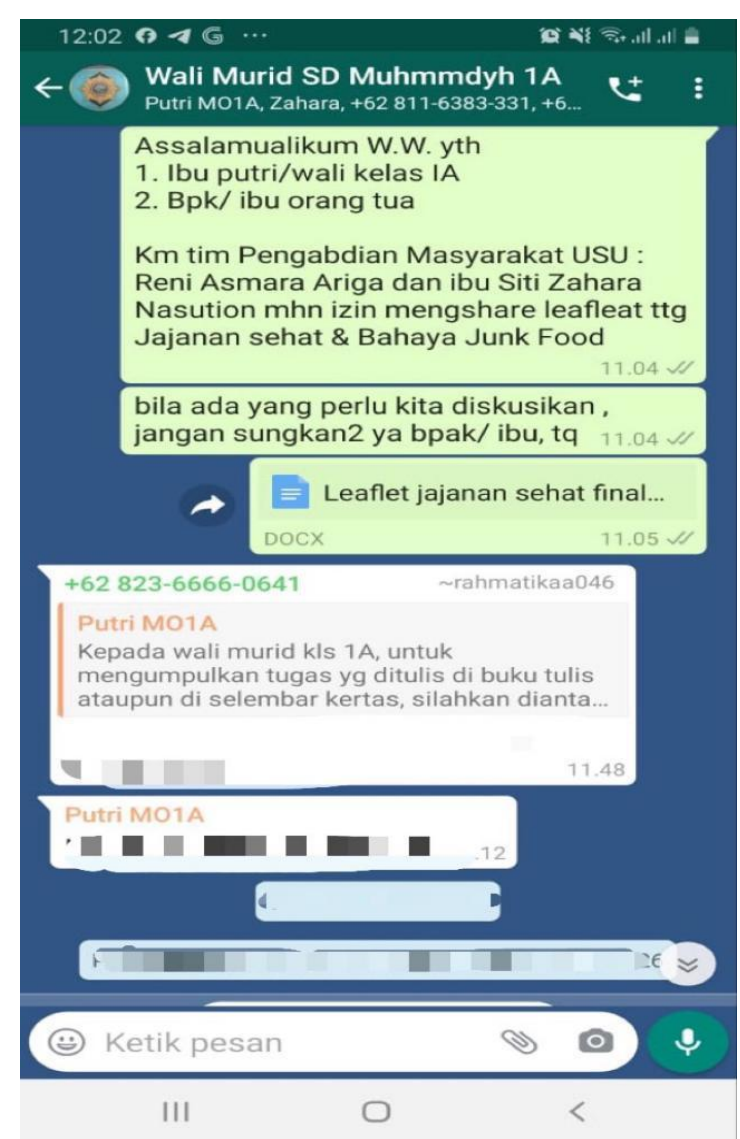

Gambar 3. Pemberian materi jajanan sehat dan bahaya junk food

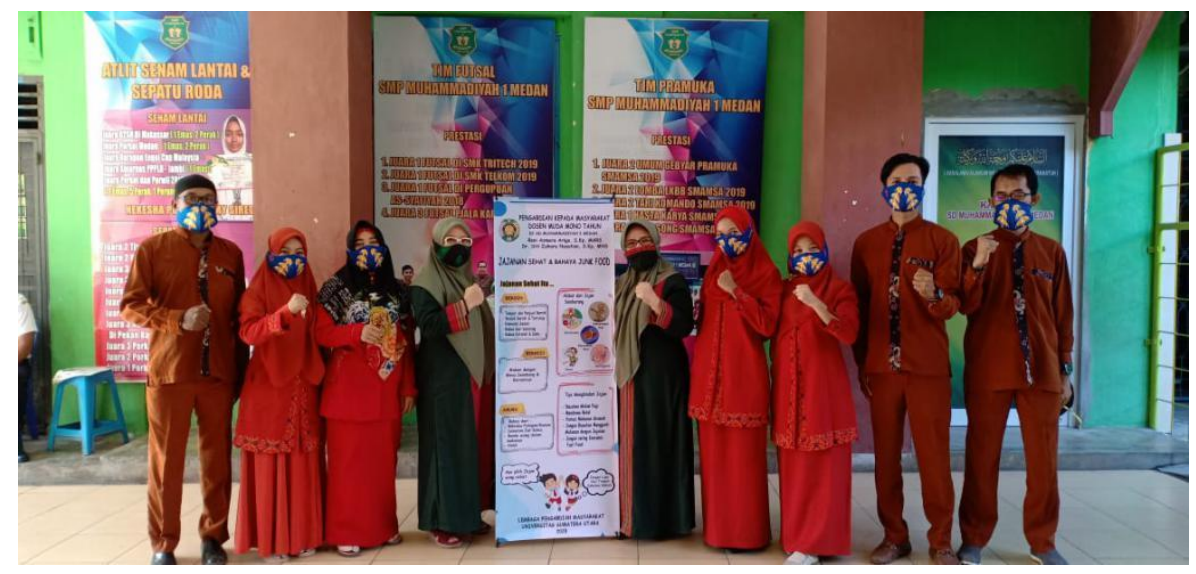

Gambar 4. Foto bersama dengan pihak sekolah dan penyerahan sarana dan prasarana

\section{Hasil}

Pada kegiatan pengabdian masyarakat di SD Muhammadiyah I Medan dilakukan edukasi kepada pihak sekolah dan orang tua terkait pelaksanaan jajanan sehat dan bahaya junk food di sekolah, sebelum dilakukan edukasi dilakukan penilaian terlebih dahulu tentang pemahaman mereka mengenai jajanan sehat dan 
bahaya junk food meliputi pengetahuan, sikap dan tindakan, kemudian diberikan edukasi dengan beberapa topik jajanan sehat dan bahaya junk food di sekolah dengan metode daring, kemudian setelah diberikan akan dilakukan kembali penilaian (post test) pada bulan September 2020 sambal menilai efektivitas edukasi yang diberikan dalam rangka peningkatan pemahaman mereka mengenai jajanan sehat dan bahaya junk food yang berguna nantinya dalam penyampaian mereka kepada siswa mengenai jajanan sehat dan bahaya junk food. Media promosi kesehatan berupa banner dan leaflet dibagikan kepada pihak sekolah dan orang tua.

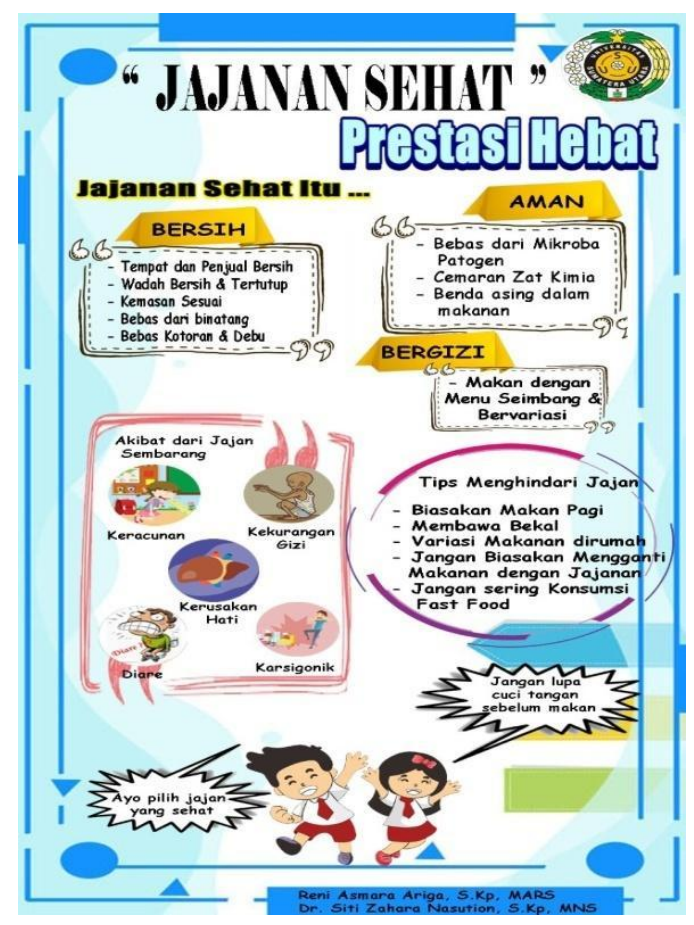

Gambar 5. Banner

Promosi kesehatan telah dilakukan kepada orang tua dan pihak sekolah sebanyak 72 orang. Hasil dari pretest dan posttest menggambarkan adanya peningkatan pengetahuan dan sikap terhadap jajanan sehat dan bahaya junk food. Dapat dilihat pada tabel 1 dan tabel 2. 
JPM: Jurnal Pengabdian kepada Masyarakat Institut Teknologi dan Bisnis Asia Malang Vol. 2, No. 1, Mei, 2021, pp. 15-24
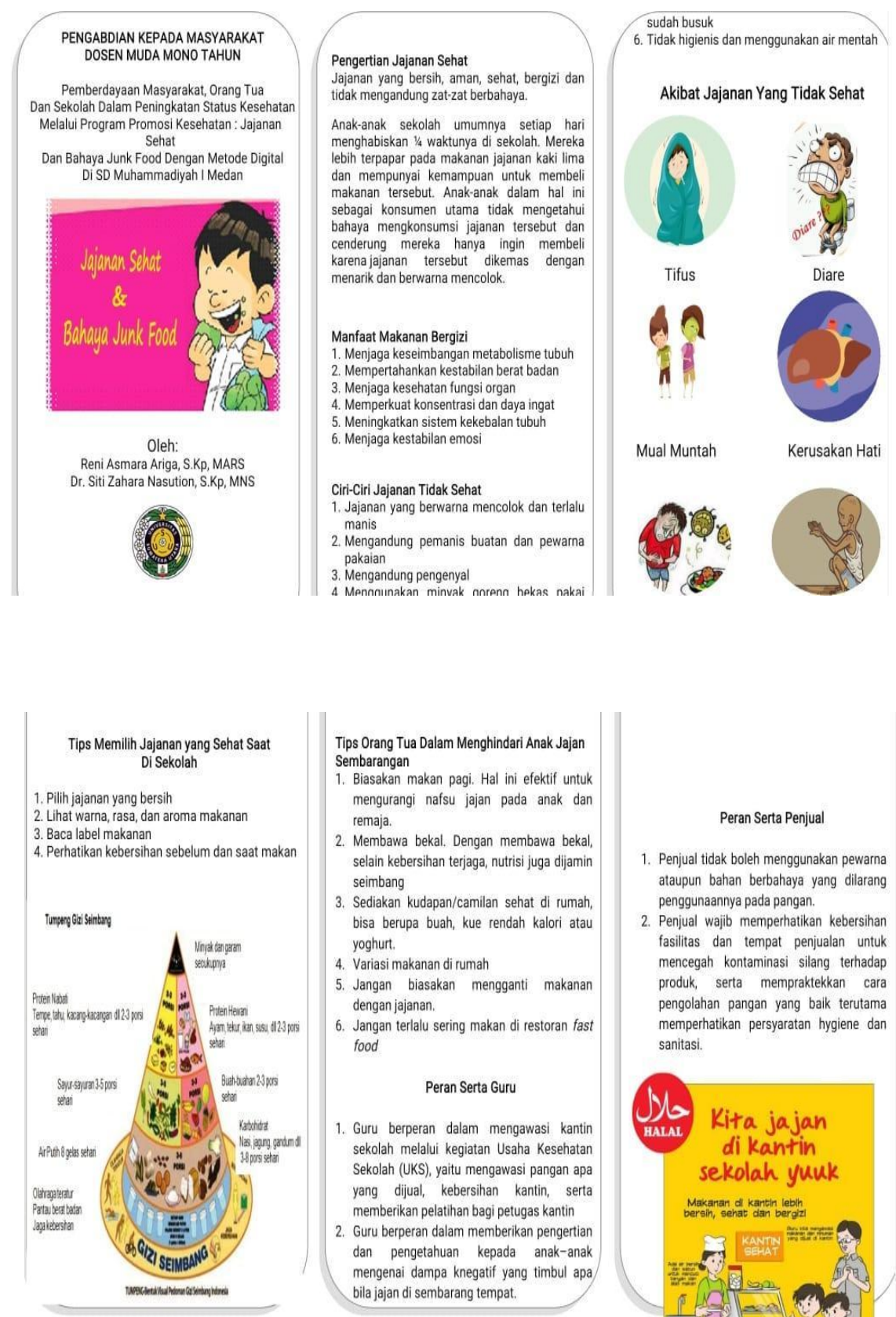

Tips Orang Tua Dalam Menghindari Anak Jajan

Sembarangan Biasakan makan pagi. Hal ini efektif untuk
mengurangi nafsu jajan pada anak dan emaja.

2. Membawa bekal. Dengan membawa bekal, selain kebersihan terjaga, nutrisi juga dijamin seimbang

3. Sediakan kudapan/camilan sehat di rumah, bisa berupa buah, kue rendah kalori atau yoghurt.

Variasi makanan di rumah

5. Jangan biasakan mengganti makanan dengan jajanan.

6. Jangan terlalu sering makan di restoran fast food

\section{Peran Serta Guru}

1. Guru berperan dalam mengawasi kantin sekolah melalui kegiatan Usaha Kesehatan Sekolah (UKS), yaitu mengawasi pangan apa yang dijual, kebersihan kantin, serta memberikan pelatihan bagi petugas kantin

2. Guru berperan dalam memberikan pengertian dan pengetahuan kepada anak-anak mengenai dampa knegatif yang timbul apa bila jajan di sembarang tempat.

\section{Gambar 6. Leaflet}

\section{Peran Serta Penjual}

1. Penjual tidak boleh menggunakan pewarna ataupun bahan berbahaya yang dilarang penggunaannya pada pangan

2. Penjual wajib memperhatikan kebersihan fasilitas dan tempat penjualan untuk mencegah kontaminasi silang terhadap produk, serta mempraktekkan cara pengolahan pangan yang baik terutama memperhatikan persyaratan hygiene dan sanitasi.

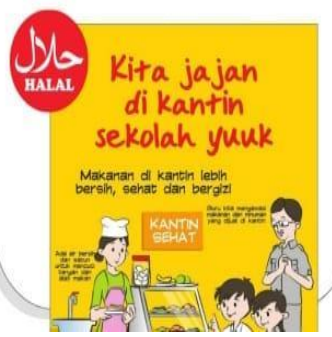

Tabel. 1 Hasil pretest dan posttest pengetahuan orangtua dan sekolah

\begin{tabular}{lcc}
\hline Pengetahuan & Pretes & Postes \\
\hline Pengertian & 10 & 15 \\
\hline Manfaat & 15 & 18 \\
\hline Ciri-ciri & 8 & 12 \\
\hline
\end{tabular}




\begin{tabular}{lcc}
\hline $\begin{array}{l}\text { Akibat jajanan sehat } \\
\text { dan bahaya junk food }\end{array}$ & 8 & 15 \\
\hline $\begin{array}{l}\text { Tips memilih jajanan } \\
\text { sehat }\end{array}$ & 9 & 12 \\
\hline Peran serta guru & 10 & 13 \\
\hline Total & 60 & 87 \\
\hline
\end{tabular}

Tabel. 2 Hasil pretest dan posttest sikap orangtua dan sekolah

\begin{tabular}{lcc}
\hline Sikap & Pretest & Posttest \\
\hline Positif & 35 & 45 \\
\hline Negatif & 25 & 40 \\
\hline Total & 60 & 85 \\
\hline
\end{tabular}

Menurut Nurbiyati (2014) jajanan berkontribusi dalam memberikan gizi dan energi pada anak usia sekolah. Oleh karena itu perlunya pendampingan kepada anak usia sekolah dalam memilih jajanan makanan di sekolah (Nurbiyati, 2014).

Diharapkan orang tua dan pihak sekolah yang sudah mendapatkan materi terkait jajanan makanan sehat dapat mengajari anak-anak untuk memilih makanan yang baik dikonsumsi dan menghindari makanan yang tidak baik dikonsumsi.

\section{Diskusi}

Anak usia sekolah lebih banyak mengkonsumsi makanan dari kantin dan street vendors sekitar sekolah karena harga yang cenderung murah dan lebih terasa enak. ${ }^{3}$ Jenis makanan jajanan di street vendors yang sering dimakan oleh anak-anak di sekolah mengandung cemaran kimiawi berupa penggunaan Bahan Tambahan Pangan yang ilegal, yaitu formalin atau yang biasa dikenal dengan pengawet untuk mayat, borax yang biasa dikenal dengan pengempal yang mengandung logam berat boron, methanil yellow yang biasa dikenal dengan pewarna kuning digunakan pada bahan tekstil dan rhodamin B yang biasa dikenal dengan pewarna merah digunakan pada tekstil. Semua bahan tersebut dapat terakumulasi di tubuh manusia dan juga bersifat racun (karsinogenik). Jika seseorang mengkonsumsi bahan-bahan tersebut dalam jangka waktu panjang, maka akan menyebabkan berbagai penyakit, seperti tumor dan kanker di organ tubuh seseorang. Sudah terungkap bahwa efek samping 
yang terjadi dari makanan yang mengandung bahan tersebut ternyata bisa berpengaruh pada fungsi otak, termasuk juga gangguan perilaku di anak usia sekolah (Kurniasih et al., 2010).

Mempertimbangkan banyaknya bahaya dalam bahan-bahan yang berbahaya pada food street dan junk food dapat membahayakan kesehatan anak usia sekolah dan juga masyarakat. Dengan diberikannya materi mengenai jajanan sehat dan bahaya. Pemberian makanan sehat dan bergizi penting untuk pertumbuhan dan perkembangan anak (Ariga et al., 2018; WHO, 2000).

\section{Kesimpulan}

Pengabdian kepada masyarakat berupa promosi kesehatan mengenai jajanan sehat dan bahaya junk food berdampak bagi orang tua dan sekolah. Hal ini dapat dilihat dari respon peserta dan hasil postest yang telah dievaluasi oleh panitia penyelenggara promosi kesehatan yaitu orangtua dan sekolah mengerti dan mengetahui jenis jenis jajanan sehat dan bahaya junk food.

\section{Pengakuan/Acknowledgements}

Apresiasi yang sebesar besarnya kami berikan kepada Rektor Universitas Sumatera Utara dan Ketua Lembaga Pengabdian Kepada Masyarakat. Apresiasi terdalam juga kami sampaikan kepada seluruh seluruh responden yang telah berpartisipasi dalam penelitian.

\section{Daftar Referensi}

Ariga, R. A., Astuti, S. B., Ariga, F. A., \& Ariga, S. (2020). Improved Knowledge and Attitude about Healthy Snack at School through Peer Education. International Journal on Advanced Science, Engineering and Information Technology, 10(4), 1662-1668. https://doi.org/10.18517

Ariga, R. A., Nasution, S. S., \& Ariadni, D. K. (2018). Community Service Activities Counseling in Making Who MP-ASI Based on Local Food for Posyandu Cadres and Baduta' Mothers. ABDIMAS TALENTA: Jurnal Pengabdian Kepada Masyarakat, 3(2), 171-175.

Foods, F. S. (n.d.). Report of an FAO technical meeting on street foods, Calcutta, 6-9 November 1995. FAO Food and Nutrition Paper, 63.

Kurniasih, D., Hilmansyah, H., Astuti, M. P., \& Imam, S. (2010). Sehat dan bugar berkat gizi seimbang. PT. Gramedia.

Lubis, Z. (2009). Hidup Sehat dengan Makanan Kaya Serat. PT Penerbit IPB Press. 
Nurbiyati, T. (2014). Pentingnya memilih jajanan sehat demi kesehatan anak. Asian Journal of Innovation and Entrepreneurship, 3(03), 192-196.

Nurmawati, S., Prodjosoewojo, S., Chairunnisa, N. H., Djauhari, H., \& Alisjahbana, B. (2019). Faktor Risiko Penyebab Foodborne Disease pada Siswa SD. Jurnal Sistem Kesehatan, 4(4).

Organization, W. H. (2000). Foodborne disease: A focus for health education. World Health Organization.

Widodo, J. (2008). Perilaku makan anak sekolah. Perilaku Makan Anak Sekolah. http://gizi.depkes.go.id/wp-content/uploads/2012/05/perilaku-makan-anak-sek olah.pdf 